\title{
Using Technologies in 21st Century: COVID-19 as an Acceleration Factor to Virtualize the World
}

\author{
Ivett Reyes Guillén \\ Faculty of Social Sciences \\ Universidad Autónoma de Chiapas, UNACH \\ San Cristóbal de Las Casas, Chiapas, México
}

\author{
Marco Polo Gallegos Cuellar \\ Member of Academic Development Directorate \\ Universidad Autónoma de Chiapas, UNACH \\ Tuxtla Gutiérrez, Chiapas, México
}

\author{
Leticia del Carmen Flores Alfaro \\ Faculty of Medicine \\ Universidad Autónoma de Chiapas, UNACH \\ Tuxtla Gutiérrez, Chiapas, México
}

\begin{abstract}
This article presents the results of a study conducted from Chiapas, Mexico, through an online survey, through Google forms, in the Spanish language. The sample was of $\mathbf{n . 3 0 0}$ and 20 states of the Mexican republic were reflected. It is study consisted of knowing the perceptions regarding the use of ICT, the stress and anxiety generated by the situation before COVID and the digitization of work, services, education, and entertainment. Among the main findings are: 1) stressanxiety is being generated $(+80 \%)$ for the use of ICTs as the only way, in many cases, to continue working during confinement by COVID, or for access to various public services and entertainment; 2) there is an increase in time for ICT use from $44 \%$ to $80 \%$ of cases using technologies more than 3 hours a day.
\end{abstract}

Keywords: ICT, COVID, Perceptions.

\section{INTRODUCTION}

From the beginning of the 21st century (2002) to today, there have been eight declared pandemics and six of them have directly damaged the respiratory system in humans (Cachicas,2020) from what infers their ability to transmit easily and quickly compared to diseases that attack other systems. This reality has, in recent years, generated the analysis of ways of restructuring societies capable of confronting them and taking care of themselves.

COVID-19, the pandemic that is going through today's world society in 2020 has led to an immediate transformation of human activities. It has been said that this pandemic has slowed the acceleration of the world; but it has not, it has streamlined it through the obligatory use of information and communication technologies (ICTs). Economies, services, offerings, and demands were made to see more powerfully in the cyber world. Local and regional governments automatically implemented digital activity so as not to slow down, mechanical activities slowed for no more than three months; but today, the acceleration is back and is greater across the digital world.

At the end of the twentieth century and the beginning of this 21 st century, even just before the start of the COVID pandemic, there was still discussion of ways to bring the world into the world using the technologies that would make us produce more agilely and reduce times, today we are reviewing how it was that all societies accelerated the use of technologies and reduced the digital divide. It turned out then that COVID-19 is an acceleration factor to virtualize the world.

The contagion prevention measures used by most countries, healthy distance, and social confinement, have been factors that led to the mastery of technologies to continue human activities from home. To be sure, in a short time there will be studies that will be counting, at the global and regional level, the reduced costs for work from home and the social benefits for it. COVID-19 arrived to remain as a virus that threatens human health; but it also came to change humanity's behaviors, ways of life, and ways of working.

Faced with this need for change of behaviors, habits, we bring to the present the theory of reflection, which expresses that the activity of learning pursues information capacity and the generation of knowledge that allow to form habits (Israel, 2004). Habit formation is an element that is pursued as a preventive and decreased form of contagion by Latin American governments in the face of the pandemic, which aims to reduce economic costs and increase health care capacity. While populations show a great ability to understand, judge and transmit information regarding the disease, the population's action measures are poor and reflected in their numbers of contagion, morbidity, and mortality.

Within this reality, the use of technologies for most economic and service activities play a leading role in ensuring, through the digitization of work, the protection of human rights by providing public services, education, prevention, and health care. Populations were sheltered and the current generation is being educated for a life that demands the self-care and safety of human populations.

The paternalistic factor of governments is a crucial element in understanding that, since social cognition, the resolution of any event must be resolved only by the government bypassing individual responsibilities (Morales and Prego, 2002); but today, for humanity in 2020, the 
situation needs to be resolved from each other for everyone and everyone, ensuring the involvement of society and government to open up new development options.

The obligatory use of technologies and the digitization of work generates several questions, within them what are the perceptions of the population regarding what is happening in their jobs and the digitization of many of them? Another question is, what about the technology professionals who have offered their profession for generations as a necessity of the future?

Based on the above, this document sets out the results of a research project on perceptions, of the Mexican population regarding the use of ICT, the stress and anxiety that generates them in addition to the digitization of work and the presence of a pandemic that has claimed thousands of lives, COVID.

\section{METHOD}

This study was conducted from Chiapas, Mexico, 2020, through an online survey, through Google forms, in Spanish. It remained on the platform until the sample reached a size of no. 300 participants. The questionnaire was structured according to the need to raise perceptions about COVID2-19 (COVID), the use of ICT, the stress and anxiety generated by the same situation (16 items).

\section{DISSCUTION}

Overall data of respondents: $56 \%$ are women and $41 \%$ male. The average age of the group is 32 years (min 12 max 74). Regarding the place of origin, the sample was represented by 20 states of the Mexican Republic, among which, the most frequently, are Tlaxcala, Chiapas, Sinaloa, Puebla, Mexico City, Veracruz, Jalisco, and Guerrero.

The level of schooling: university studies (60\%); postgraduate (26\%), high school (12\%) (2\%). It is important to mention, that the percentage of university and/or graduate women was higher compared to men by 4 and $7 \%$ respectively. In this regard, the use of technologies affected $68 \%$ of women who participated in this study and $73 \%$ of men in their employment or studies during the pandemic.

In recent decades, gradually, the expansion of new communication and information technologies has contributed to social changes, acceleration of processes and synergies, globalized and instant information (Women's Institute, 2008); but without a doubt, in 2020, it went from being a gradual and even selective process, to an accelerated and imperative process. The digital divide in society and between genders was even broader and more noticeable; Today this gap is closing and shows, in our findings that, women are present with higher school levels and with technology management as part of their daily work activities, which coincides with what Zenker reported in 2004.

Fear-stress-anxiety: As for the explanation of the condition they felt towards their employment or studies, by the accelerated use of technologies, the main reason for women is that they fear or generate stress in $85 \%$ of cases, and/or anxiety in $59 \%$ of cases.

For men, the numbers are similar, fear-stress and anxiety are present in $82 \%$ and $59 \%$ of cases, respectively. There is no significant difference when comparing the two cases between genders.

Faced with the set of environmental demands that humans receive (labor, family, health, love...) and that need to be taken care of, emotional responses such as anxiety, which can be seen as an emotional reaction of alertness, are generally seen as a threat by stressful agents (Valdés y Flores, 1990; Turner et al, 1995; Sierra et al, 2003). Stress can manifest itself through anxiety, and in this case, it is being generated using ICTs as the only way, in many cases, to continue working during COVID confinement, or for access to various public services.

Daily time of use of Information and Communication Technologies: Making a comparison between before COVID and the current reality with the presence of COVID, this study shows us an increase in time for the use of ICT, has doubled from $44 \%$ to $80 \%$ of cases using technologies more than 3 hours a day. While it is true that, since the emergence by COVID the use of ICT has accelerated, it is also true that much has been done and written, since the end of the last century and in the present, for the use of technologies, starting from the development of digital skills at the different educational, labor, commercial and even entertainment levels (Guerra et al 2008; White 2009; Mint 2012; Guadarrama, 2012).

Of the total sample, $74 \%$ consider having knowledge of more than $50 \%$ of the proper management of ICTs. The remaining percentage considers that their knowledge ranges from $10-40 \%$. Nevertheless, $55 \%$ claim to have courses for the use of technologies and only $13 \%$ have professional training. With regard to having their own computer equipment that facilitates their activities in virtual mode, $92 \%$ have this equipment; $8 \%$ do not have their own team, the latter contrasting with the $15 \%$ that Zenker reported for 2004; that is, that percentage of people who do not have their own equipment has declined in recent years and would be expected to shrink further in the current situation.

Moreover, with regard to the need for technical assistance to carry out their activities through the use of ICTs, $67 \%$ claim to need this advice; and consider that the most appropriate way to obtain this help would be the telephone $(41 \%)$, although also mentioned the e-mail channels $(8 \%)$, chat $(18 \%)$ physically $(32 \%)$. However, $36 \%$ say they would not pay for the technical aid service, the remaining percentage would do so in full $(12 \%)$ or partially $(21 \%)$.

Castellanos and collaborators (2009) comment that the technology is interpreted from a wide perspective and there are difficult and soft components involved; but that there are significant differences between countries with emerging and 
developed economies, as the former often ignore technologies, products and professionals, within the goods and services industry. This has changed in recent years, however, as we see in this study, the percentage of people who do not choose to pay for this type of technical and/or professional services is still high.

Finally, the results show that IT is considered that COVID's confinement is more time spent in ICTs than in other activities; because it is useful to them, 96\%, for various activities or services such as school learning, communications, entertainment, work and commerce. However, 4\% think it has many disadvantages to use ICTs because they are at risk and harming health and society. The latter, coupled with the reluctance not to pay for a technical assistance service for the correct use of ICTs, leads us to analyze the permanence of the digital divide; but also, to visualize that the activities now structured and carried out in a virtual way, require us, not to slow down and guarantee social, economic, educational, cultural life permanently active.

In 1995, the concept of digital divide was disseminated, through the U.S. National Telecommunications and Information Administration's Falling Throigh the Net: a survey of the 'have nots' in rural and urban America. This report has been analyzing the variables related to access to technologies, being useful for public policies and providers of these services and products (Rodríguez, 2006). The discussion today has surely taken a hasty turn, which, while the digital divide, generated by socioeconomic variables, make clear the great inequities, it is also true that in the reality of 2020 before COVID and its measures for risk mitigation, ICTs play a leading role, no matter the level of development of each country, because we are all embedded in a totally globalized dynamic.

\section{CONCLUTIONS}

The perceptions, of the Mexican population, regarding the use of ICT, the stress and anxiety generated by the same situation, where the digitization of work and the presence of a pandemic that has claimed thousands of lives, are:

- $56 \%$ of women and $41 \%$ of men, with an average age of 32 years, participated in the survey, indicating to a young population.

- The percentage of college and/or graduate women was higher than men.

- The frequency in ICT use, fear of this, stress and anxiety generation exceed $80 \%$ of cases in both men and women.

- Stress-anxiety is being generated using ICTs as the only way, in many cases, to continue working during COVID confinement, or for access to various public services.

- There is an increase in time for ICT use from $44 \%$ to $80 \%$ of cases using technologies more than 3 hours a day.

- $92 \%$ have their own computer equipment that facilitates their activities in virtual mode.

- $67 \%$ believe that they need technical support for the use of ICTs; but only $33 \%$ would pay for this service.
- The activities now structured and carried out in a virtual way require us not to slow down and guarantee the social, economic, educational, cultural life permanently active.

\section{REFERENCES}

[1]. Cachicas, V. (2020) "El mundo está alerta a epidemia por neumonías causadas por el coronavirus relacionado al consumo de animales silvestres: la historia se repite" Rev. Inst. Salud Pública Chile. Vol.4, No.1. Chile. DOI: doi.org/10.34052/rispch.v1i1.91

[2]. Israel Núñez, P. (2004) "Las necesidades de información y formación: perspectivas sociopsicológica e informacional" ACIMED Vol.12, No.5. Recuperado en Julio 2020 de http://scielo.sld.cu/scielo.php?script=sci_arttext\&pid= S1024-94352004000500004\&lng=es\&tlng=pt.

[3]. Morales López, E. y Prego Vazquez, G. (2002) "Entrevistas electorales en las campañas políticas para la presidencia del gobierno de 1996 y 2000" Editorial Arco/Libros. Chile

[4]. Instituto de la Mujer (2008). Mujeres y nuevas tecnologías de la informacióny la computación. Madrid. 307pp.

[5]. Zenker, A (2004). "Navegan más las mujeres". Reforma, mayo 10 (2004): Cultura, 2C

[6]. Valdés, M. \& Flores, T. (1990). Psicobiología del estrés (2a ed. Actual.). Barcelona: Martínez Roca.

[7]. Turner, R. J., Wheaton, B. \& Lloyd, D. A. (1995). The epidemiology of social stress. American Sociological Review, 60, 104-125.

[8]. Sierra JC y Ortega V y Zubeidat I (2003). Ansidedad, angustia y estrés: tres conceptos a diferenciar. Revista Mal-estar E Subjetividade 3(1), 10-59

[9]. Guerra, M.A, Moreno, I. y Marquina, R. (2008). Nativos e Inmigrantes Digitales. Recuperado el 15 de octubre del 2016. Consultado en: http://www.protecciononline.com/\%C2\%BFque-es-unnativo-digital-y-unmigrante-digital/

[10]. Blanco, A. (Ed.). (2009). Desarrollo y Evaluación de Competencias en Educación Superior. Editorial:Narcea

[11]. Acuña, A. (2012). Competencias tecnológicas en los alumnos de secundaria y bachillerato. El uso de las Tecnologías de Información y la Comunicación (TIC) en la Educación. ANUIES.

[12]. Guadarrama, H. (2012). Competencias docentes. México: ESFINGE

[13]. Castellanos DOF, Jiménez HC, y Domínguez MK (2009). Competencias tecnológicas: bases conceptuales para el desarrollo tecnológico en Colombia. Revista ingeniería e investigación. Vol. 29 No. 1 P. 133-139

[14]. Rodríguez GA (2006). La brecha digital y sus determinantes. UNAM. 254 pp. 